\title{
Kontribusi Pelatihan dalam Meningkatkan Keterampilan Guru Membimbing Siswa Bermain Balok
}

\author{
M. Masnipal \\ Pendidikan Guru Pendidikan Anak Usia Dini, Universitas Islam Bandung, Indonesia \\ DOI: $\underline{10.31004 / \text { obsesi.v6i3.1745 }}$
}

\begin{abstract}
Abstrak
Salah satu cara mengembangkan kreativitas anak usia dini melalui permainan konstruktif (balok). Indonesia masih jarang dikembangkan teknik permainan balok. Beberapa teknik dari luar sulit diaplikasikan guru PAUD di Indonesia. Model Pengembangan Kreativitas Permainan Konstruktif (PKPK) dikembangkan tahun 2008 dan direkonstruksi 2019 pada skenario dan tahapan disesuaikan jenis balok untuk mempermudah guru dan telah diuji efektivitasnya. Penelitian menguji apakah pelatihan model PKPK berkontribusi dalam meningkatkan keterampilan guru membimbing siswa bermain. Penelitian menggunakan pre-experimental dengan one-group pretest-posttest design. Alat pengumpul data menggunakan observasi dan ceklis. Analisis data menggunakan statistik deskriptif. Temuan penelitian menunjukkan pelatihan berkontribusi meningkatkan keterampilan guru dalam: (a) menguasai prosedur, skenario, tahapan bermain; (b) melaksanakan kegiatan bimbingan bermain secara menarik dan menyenangkan; (c) kemudahan menggunakan alat main dan pengaturan waktu, (d) kemampuan menilai siswa. Peningkatan tersebut diikuti partisipasi siswa dan efektivitas bermain. Hasil penelitian berimplikasi bagi guru untuk mengikuti pelatihan sebelum mengaplikasikan model PKPK di lembaga PAUD.
\end{abstract}

Kata Kunci: pelatihan guru, permainan balok, model PKPK, anak usia dini.

\begin{abstract}
One way to develop early childhood creativity is through constructive plays (blocks). Indonesia, the technique of playing blocks is still rarely developed. Some of the techniques introduced from outside are difficult for PAUD teachers to apply in Indonesia. The Model Pengembangan Kreativitas Permainan Konstruktif (PKPK) was developed in 2008 and reconstructed in 2019 in scenarios and stages adapted to the type of block to make it easier for teachers and its effectiveness has been tested. The study tested whether the PKPK model training contributed to improving the skills of teachers in guiding students to play. The study used a pre-experimental one-group pretestposttest design. Data collection tools using observations and checklists. Data analysis used descriptive statistics. Research findings show that training contributes to improving teachers' skills in: (a) mastering procedures, scenarios, stages of play; (b) carry out play guidance activities in an interesting and fun way; (c) ease of use of play tools and timing, (d) ability to assess students. The increase was followed by student participation and play effectiveness. The results of the study have implications for teachers to attend training before applying the PKPK model in PAUD institutions.
\end{abstract}

Keywords: teacher training, block play, PKPK model, early childhood.

Copyright (c) 2021 M. Masnipal.

$\triangle$ Corresponding author:

Email Address: masnipalmarhun@gmail.com (Bandung, Indonesia)

Received 13 May 2021, Accepted 20 September 2021, Published 29 September 2021 


\section{PENDAHULUAN}

Di berbagai belahan dunia terutama negara-negara maju, permainan balok (block play) telah dikenal sejak lama dan menjadi salah satu permainan popular di kalangan anak usia dini. Seiring perkembangan zaman, banyak jenis balok telah diproduksi dengan tujuan, fungsi dan tingkat kesulitan berbeda-beda. Mengingat pentingnya permainan balok bagi anak usia dini, hampir di setiap lembaga taman kanak-kanak di Indonesia, terutama di kotakota menyediakan alat permainan balok di sekolah mereka. Akan tetapi berdasarkan hasil observasi di beberapa taman kanak-kanak di Kota Bandung dan Cimahi menunjukkan bahwa hampir seluruh siswa tidak dapat bermain balok sesuai fungsinya. Permainan balok hanya menjadi kegiatan iseng, bahan lemparan sesukanya, semata-mata kesenangan dan tidak memiliki tujuan (Masnipal, 2008, 2016, 2020). Padahal jika dilakukan dengan cara-cara benar permainan balok dapat membantu tugas perkembangan anak, termasuk kreativitas, kelenturan motorik halus, spasial, bahasa,dan matematik (Cohen \& Emmons, 2017; Hanline et al., 2010; Pankratz, 2015).

Beberapa studi lain tentang manfaat permainan balok (konstruktif) menyimpulkan bahwa permainan balok dapat membantu anak dalam mengembangkan imajinasi, keterampilan manipulasi, pengalaman kreatif, dan dramatik (Dodge. D. T. et al, 2002; Pankratz, 2015); meningkatkan kemampuan numerikal (Bojorque. G. et al, 2018); meningkatkan kemampuan matematik yakni berhitung, mengenal bentuk, dan bahasa matematika (Pirrone et al., 2018; Schmitt. S. A. et al, 2018). Studi lain dari (Hanline et al., 2010) menyatakan adanya hubungan yang erat antara bermain balok para anak prasekolah dengan kemampuan membaca dan matematika. Casey, (Casey. B. M. et al, 2008) mengungkap bahwa kegiatan permainan balok membangun dapat meningkatkan perkembangan keterampilan spasial. Permainan balok juga secara natural bagi anak-anak dapat mengembangkan keterampilan dalam mengobservasi, komunikasi, bereksperimen, dan kemampuan konstruksi (Cohen \& Emmons, 2017). Studi dari (Bairaktarova et al., 2011) mengungkapkan bahwa permainan balok membangun sebagai dasar awal keterampilan teknik sipil dan arsitektur.

Banyak model atau teknik telah dikembangkan para ahli untuk membantu siswa agar permainan balok mencapai sasaran sesuai tujuan (Dodge. D. T. et al, 2002; Hanline et al., 2010; Hirsch. E, 1984; Hoorn. J. V. et al, 1993). Kebanyakan dari model tersebut melibatkan peran orang dewasa sebagai pembimbing. Keterlibatan orang dewasa, seperti guru dan orangtua sangat penting untuk membantu siswa bermain (Kellar-Guenther et al., 2014) seperti dalam persiapan alat, memperkenalkan potongan balok, hingga menyusun bangunan struktur (Otsuka \& Jay, 2017).

Model Pengembangan Kreativitas Permainan Konstruktif (PKPK) merupakan salah satu teknik permainan balok untuk anak usia dini yang dikembangkan oleh Masnipal tahun 2008 dan direkonstruksi tahun 2019. Rekonstruksi dilakukan karena adanya masukan dari guru-guru yang telah mengaplikasikan model PKPK di sekolah. Sebagian mereka mengalami kesulitan melaksanakan proses bimbingan (guided play) pada pertemuan ke-1 sebelum siswa dilepas bermain sendiri (free play) untuk memberi kesempatan proses kreatif berjalan. Di samping itu, waktu bimbingan dalam pertemuan ke-1 untuk membimbing tiga kelompok/jenis alat balok sekaligus yang memiliki tingkat kesulitan berbeda terlalu singkat. Rekonstruksi model dilakukan dengan mengembangkan skenario dan tahapan bermain sesuai tingkat kesulitan jenis/kelompok balok dan menambahkan durasi dari 1 menjadi 2 kali untuk memberi kesempatan guru melakukan proses bimbingan bermain. Dari rekonstruksi ini menghasilkan tiga skenario dengan tahapan bermain berbeda untuk setiap kelompok/jenis balok. Dengan demikian, setiap jenis/kelompok balok konstruktif memiliki skenario, tahapan bermain, tugas guru, dan alat penilaian berbeda serta menambahkan menjadi 2 pertemuan pada proses bimbingan bermain. Hasil rekonstruksi telah dipublikasikan pada Jurnal Early Chilhood Care and Education (JECCE) dikelola oleh Program Studi PG PAUD, Universitas Ahmad Dahlan Vol. 3 No.1 Maret 2020. Sebelum 
direkonstruksi, model PKPK sempat dipublikasikan di Jurnal Pendidikan Islam Ta'dib, Fakultas Tarbiyah dan Keguruan Universitas Islam Bandung pada 2017.

Model PKPK dimaksudkan membantu guru PAUD dalam membimbing anak usia dini bermain konstruktif (balok, lego, mobis, lasy) untuk mengembangkan kemampuan berpikir kreatif (kreativitas). Keunggulan model PKPK dibanding dengan model sejenis, memiliki skenario permainan yang jelas dan rinci menuju proses kreatif. Tahapan bermain dalam model PKPK juga sangat sederhana sehingga memudahkan guru dan siswa bermain. Tahapan yang banyak dan berbeli-belit akan menjadi beban bagi guru dan dapat membuat siswa stres. Efektivitas model sebagai pengembang dan pemacu kreativitas telah diuji melalui Tes Kreativitas Figural (TKF) atau Circle Test dari Torrance tahun 1974 (Kaufmann, 2006) dan dikembangkan oleh Prof. Dr. Utami Munandar dan kawan-kawan pada tahun 1988 di Fakultas Psikologi Universitas Indonesia. Adaptasi TKF untuk menguji efektivitas model PKPK dibimbing langsung oleh pakar kreativitas Indonesia, Prof. Dr. Utami Munandar.

Model PKPK dikembangkan mengacu kepada model Hirsh dan Dodge, (Dodge. D. T. et al, 2002; Hirsch. E, 1984; Hoorn. J. V. et al, 1993). Model PKPK terdiri dari tiga kelompok balok yang masing-masing dilengkapi dengan tiga skenario permainan, tahapan bermain, tugas guru, alat penilaian siswa, dan petunjuk penggunaan yang berbeda. Kelompok balok A yaitu BM-16, BM-49 dan BM-104; kelompok B adalah BH-55, BT-83, GB-86, BS-145; dan kelompok $C$ yaitu MOBIS 60 dan L-100. Ketiga kelompok balok tersebut memiliki tingkat kesulitan berbeda-beda, jenis balok A lebih mudah dimainkan dibanding balok B sehingga cocok bagi pemula, dan balok B lebih mudah dibanding balok $\mathrm{C}$. Balok B dan C lebih tepat untuk siswa sudah lebih mahir. Kelompok balok A dan B dirancang dalam lima tahapan main, sedangkan kelompok $C$ terdiri dari 6 tahapan.

Model PKPK menggunakan metode bermain dengan bimbingan (guided play), walaupun pada tahapan proses kreatif siswa bermain bebas (free play). Studi tentang penggunaan metode bermain dengan bimbingan dalam bermain balok dilakukan oleh (Ferrara.K. et al, 2011) (Ramani et al., n.d.), sedang pemanfaatan bermain bebas oleh (Bergen. D, 2002; Brown. S, 2009; Hyson, 2004) Keunggulan model ini dibandingkan dengan model sejenis, di antaranya (i) mudah dalam penggunaannya karena dilengkapi skenario permainan untuk setiap kelompok jenis balok; (ii) terdiri dari tahapan-tahapan sederhana yang mudah diikuti guru atau siswa; (iii) dilengkapi dengan tugas guru, baik sebagai pengamat (observing), pembimbing (guiding), dan penilai (asesing); (iv) model dilengkapi ceklis penilaian kemampuan siswa.

Di lembaga PAUD, efektivitas permainan balok yang dilakukan anak usia dini sangat tergantung dari guru. Persoalannya tidak semua guru memiliki keterampilan atau kompetensi dalam membimbing permainan balok (Otsuka \& Jay, 2017). Untuk kepentingan itu, sebaiknya guru sebelum melaksanakan kegiatan bermain mengikuti pelatihan terlebih dahulu. Pelatihan akan memberi panduan kepada guru tentang cara-cara bermain, termasuk prosedur, skenario dan tahapan yang harus diikuti. Beberapa studi menunjukkan bahwa pelatihan, workshop, bimbingan teknis, pelatihan dalam jabatan hingga studi lanjutan dapat meningkatkan kompetensi atau keterampilan profesional guru (Nagovitsyn et al., 2016; Palomino, 2017; Vodyasova, L. P., \& Morozova, n.d.).

Pelatihan merupakan salah satu strategi yang dilakukan oleh institusi atau lembaga untuk meningkatkan kompetensi guru. Pelatihan dapat memodifikasi perilaku guru dengan berbagai intervensi (Bailey \& Van Harken, 2014; Hyatt \& Filler, 2007). Penelitian lain juga menyebut adanya dampak peningkatan konsep dan keterampilan guru setelah pelatihan keterampilan mengajar (Gliessman \& Pugh, 1994). Pelatihan bagi guru anak usia dini berkontribusi terhadap kemampuan dan keterampilan dalam menangani anak (Loizou, 2009; Melhuish et al., 2016; Pereira, 2009).

Pelatihan teknik permainan balok menggunakan model PKPK bertujuan membimbing guru agar menguasai teknik permainan balok, sebelum mereka melaksanakan kegiatan permainan balok kepada siswa mereka. Sejak diperkenalkan tahun 2019, pelatihan 
teknik permainan konstruktif model PKPK telah diikuti sekitar 300 guru PAUD di kota Bandung, Cianjur, kota Cimahi dan Kabupaten Bandung. Pelatihan terakhir sebelum pandemi covid 19, dilaksanakan pada 5 Oktober 20219 di tiga Kecamatan Cicalengka, Cikancung, dan Nagrek Kabupaten Bandung, yang diikuti 90 orang. Pelatihan yang terakhir di Kabupaten Bandung ini yang digunakan sebagai subjek dan lokasi penelitian.

\section{METODOLOGI}

Penelitian ini hanya memfokuskan diri kepada pelatihan teknik permainan model PKPK menggunakan kelompok balok A yakni penggunaan balok jenis BM 16, BM 49, dan BM 104, meskipun model ini terdiri dari tiga jenis kelompok balok. Kelompok balok A diberikan sebagai pelatihan dasar kepada guru sebelum bermain kelompok balok B atau C dengan alasan lebih mudah. Pertimbangan lainnya karena hampir seluruh lembaga RA di 3 wilayah pengujian memiliki balok kelompok A, sehingga jenis balok tersebut sudah sangat dikenal guru.

Pelatihan berdurasi 1 X 4 jam efektif untuk 1 jenis balok, meliputi 3 tahapan: Pertama, pengantar (jenis balok, skenario dan tahapan permainan, tugas guru, dan alat evaluasi) selama 45 menit menggunakan slide. Kedua, instruktur memperagakan teknik permainan sesuai skenario dan tahapan permainan. Ketiga, peserta pelatihan mempraktikkan teknik permainan dalam kelompok-kelompok kecil terdiri dari 2-4 orang dan dilanjutkan secara perorangan dengan bimbingan instruktur. Keempat, setelah dua minggu setelah pelatihan, guru melaksanakan kegiatan permainan dengan siswa di sekolah.

Teknik permainan model PKPK menggunakan balok kelompok A mengikuti skenario dan tahapan permainan sebagaimana gambar 1 . Dalam gambar tersebut pada pertemuan ke1 dan ke-2 (P1-P2), peserta dilatih bagaimana mempersiapkan alat main, melaksanakan kegiatan main, dan menilai sesudah main. Tahapan ini merupakan tugas guru dalam menyiapkan, membimbing (guiding) mengamati (observing), dan menilai (assesing) siswa bermain, sehingga harus benar-benar dikuasai guru. Sedangkan pertemuan ke-3, 4, 5, (P-3, P-4, P-5), dan seterusnya merupakan proses kreatif, dimana siswa diberi kesempatan untuk mengembangkan kreativitasnya. Tugas guru pada tahap ini hanya mengamati dan menilai setelah siswa selesai bermain.

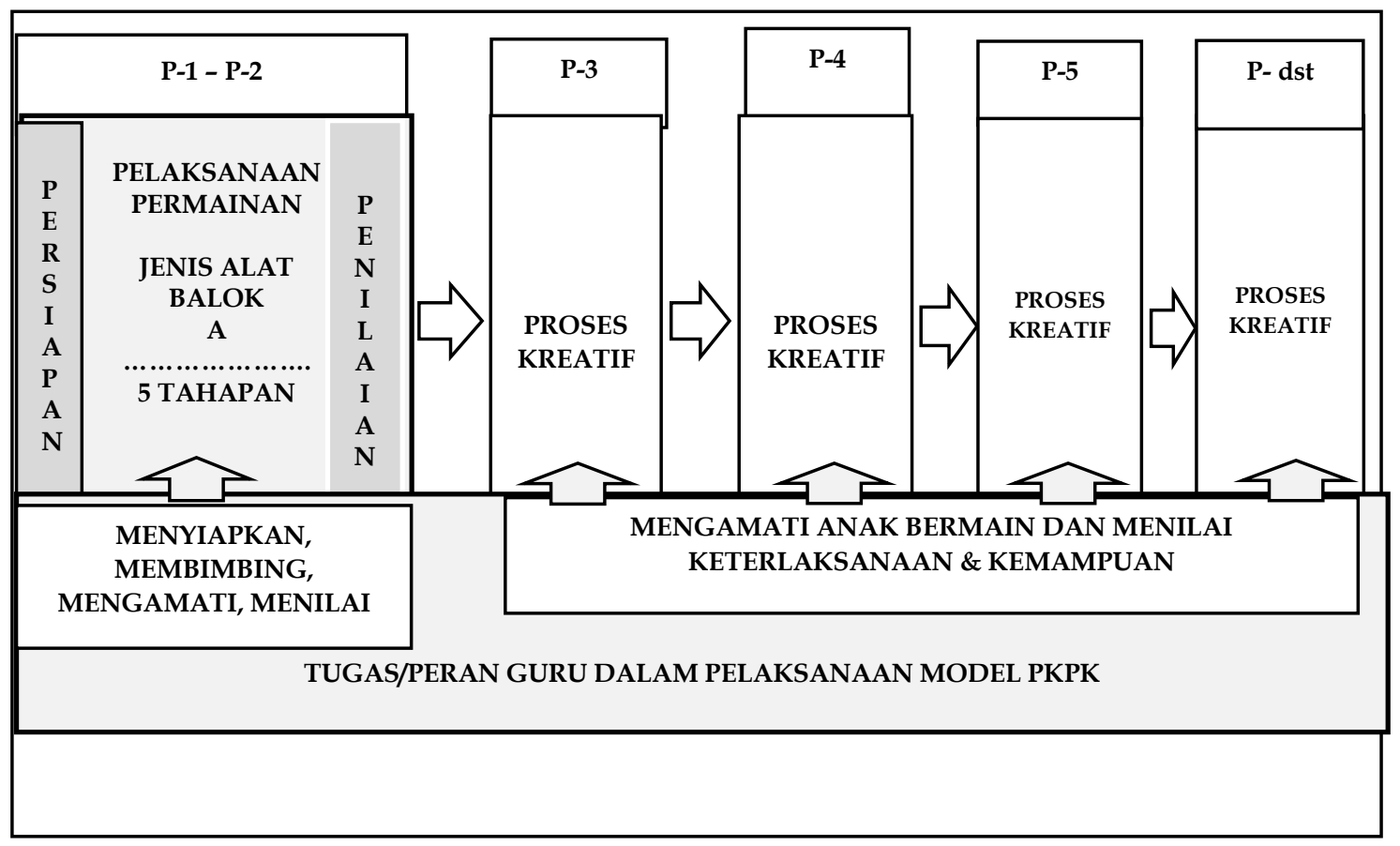

Gambar 1: Skenario Permainan dan Proses Kreatif Balok Kelompok A Model PKPK 
Tahapan permainan model PKPK menggunakan kelompok balok A terdiri dari lima tahapan, tabel 1.

Tabel 1: Tahapan Bermain Model PKPK Balok

\begin{tabular}{cl}
\hline Tahap 0 & $\begin{array}{l}\text { Persiapan tempat dan alat main; }(\mathrm{b}) \text { penjelasan tentang jenis, nama dan } \\
\text { jumlah potongan balok; (c) mempraktikkan cara memasang, } \\
\text { menyatukan, dam mengkombinasikan. }\end{array}$ \\
\hline Tahap 1 & Memasang tiang pancang dengan tegak \\
\hline Tahap 2 & Menghubungkan potongan balok menciptakan struktur \\
\hline Tahap 3 & $\begin{array}{l}\text { Melengkapi bangunan struktur dengan perlengkapan pagar, garasi, } \\
\text { kandang, jembatan, dll. }\end{array}$ \\
\hline Tahap 4 & $\begin{array}{l}\text { Menambah bangunan struktur dengan dekorasi orang, alat rumah } \\
\text { tangga, kendaraan, binatang, tanaman, dll. }\end{array}$ \\
\hline Tahap 5 & Memberikan nama bangunan dan menginterpretasikannya. \\
\hline
\end{tabular}

Dalam permainan tersebut, guru bertugas, tabel 2 .

Tabel 2: Tugas Guru Dalam permainan Balok Model PKPK

\begin{tabular}{|c|c|c|}
\hline Tahapan & Tugas Guru & Kegiatan Guru \\
\hline \multirow[t]{4}{*}{ Persiapan } & \multirow{4}{*}{$\begin{array}{l}\text { Sebagai } \\
\text { organisator } \mathcal{E} \\
\text { fasilitator }\end{array}$} & Mempersiapkan tempat atau ruangan bermain \\
\hline & & Menyiapkan media/alat bermain. \\
\hline & & Mengorganisasikan anak bermain. \\
\hline & & $\begin{array}{l}\text { Menyampaikan informasi tentang aturan-aturan } \\
\text { bermain (aturan cara mengambil alat dan } \\
\text { menyimpan kembali). }\end{array}$ \\
\hline & Melaksanakan & Guru memberikan membimbing kepada siswa \\
\hline \multirow[t]{5}{*}{$\mathrm{P}-2$} & bimbingan & $\begin{array}{l}\text { cara bermain Model PKPK sesuai jenis alat dan } \\
\text { tahapannya (satu kali atau dua kali tergantung } \\
\text { kemampuan siswa) }\end{array}$ \\
\hline & & Guru memberikan kesempatan siswa bermain \\
\hline & \multirow{3}{*}{$\begin{array}{l}\text { Mengamati } \\
\text { dan menilai } \\
\text { siswa }\end{array}$} & Guru mengamati siswa bermain \\
\hline & & $\begin{array}{l}\text { Guru melihat dan mendengar apa yang } \\
\text { dikatakan anak. }\end{array}$ \\
\hline & & $\begin{array}{l}\text { Guru menilai siswa bermain melalui lembar } \\
\text { ceklis. }\end{array}$ \\
\hline P-3 & Mengamati & $\begin{array}{l}\text { Siswa dibiarkan bermain sendiri/berkelompok } \\
\text { secara bebas, rileks, tanpa campur tangan guru, } \\
\text { kecuali hanya mengamati. }\end{array}$ \\
\hline $\begin{array}{l}\text { P-4, P-5, } \\
\text { P-6, dst }\end{array}$ & Mengamati & sda \\
\hline
\end{tabular}

Untuk mengetahui kontribusi pelatihan dalam meningkatkan keterampilan guru membimbing siswa bermain balok mengggunakan model PKPK, penelitian menggunakan pendekatan Pre-experimental dengan One-Group Pretest-Posttest Design. Dengan demikian, penelitian hanya menggunakan satu kelompok subjek, pretes, perlakuan, dan postes (Bernard, 2013; Bryman, 2016; Creswell, n.d., 2014). Penelitian dilakukan terhadap satu kelompok (populasi) guru yang telah mengikuti pelatihan dan telah melaksanakan teknik permainan balok model PKPK di Raudhatul Athfal (RA), berjumlah 68 ((75,6\%) dari 90 peserta yang ikut pelatihan pada 5 Oktober 2019 berasal dari tiga Kecamatan Nagrek, Cicalengka, dan Cikancung, Kabupaten Bandung. Sedangkan $22(24,4 \%)$ peserta lainnya tidak dijadikan subjek 
penelitian karena mereka mengikuti pelatihan tapi tidak menerapkan model tersebut di lembaga mereka dengan berbagai pertimbangan, sehingga tidak dilakukan postes.

Penelitian mengikuti langkah, pertama, peneliti melakukan pretes terhadap guru sebelum pelatihan dimulai selama 60 menit. Perangkat pretes berupa instruksi penggunaan model dan teknik penerapannya. Untuk menilai kemampuan guru, peneliti menggunakan lembar observasi berupa ceklis. Kedua, peneliti dibantu beberapa orang instruktur melaksanakan pelatihan (perlakuan) selama 5 jam $(1 \times 5$ jam $)$ mulai dari persiapan dan penggunaan alat main, pelaksanaan bermain (skenario, tahapan, pengaturan waktu, dan tugas guru sebagai pembimbing, pengamat, dan penilaian permainan siswa. Ketiga, setelah selesai pelatihan para guru diberi kesempatan mengaplikasikan teknik permainan balok kepada siswa di lembaga mereka dalam empat minggu (4-8 kali pertemuan bermain). Keempat, bagi guru yang telah menerapkan model PKPK di lembaga mereka dilakukan postes oleh teman sejawat (salah seorang guru yang pernah ikut pelatihan) dengan observasi (ceklis). Lembar observasi berupa ceklis keterampilan guru dalam mengikuti skenario permainan dengan lima tahapan dalam model PKPK, dimulai persiapan alat, memasang tiang pancang hingga menginterpretasikan bangunan struktur. Rancangan penelitian, gambar 2.

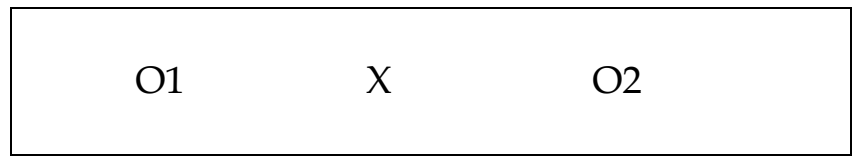

[Creswell, 2014]

\section{Gambar 2: Rangcangan Penelitian}

Keterangan:

$\mathrm{O} 1=$ nilai pretes (sebelum perlakuan)

$\mathrm{X}=$ perlakuan (pelatihan teknik permainan balok)

$\mathrm{O} 2=$ nilai postes (sesudah perlakuan)

Subjek penelitian adalah guru raudhatul athfal yang hadir mengikuti pelatihan dan bersedia mengaplikasikan hasil pelatihan kepada siswa di lembaga mereka. Alat pengumpulan data menggunakan observasi berupa ceklis kemampuan guru. Validasi instrumen oleh pertimbangan ahli (judge expert). Subjek penelitian dipilih atas pertimbangan: (a) belum pernah mengikuti pelatihan serupa; (b) bersedia mengaplikasikan hasil pelatihan kepada siswa di sekolahnya.

Dari 68 orang yang menjadi subjek penelitian memiliki tingkat pendidikan dan pengalaman atau lama mengajar yang sama atau hampir sama atau sebanding. Dengan demikian ancaman dari validitas internal dapat dikendali (Setyosari, 2013). Ancaman berkaitan validitas eksternal adalah (a) subjek penelitian bertindak berbeda dari yang diharapkan (b) Subjek sudah mengatur situasi dan kondisi peserta didik sebelum observasi berlangsung; (c) kemungkinan ada subjek yang tidak secara konstinu menerapkan teknik permainan sesuai skenario dan tahapan model PKPK sehingga mengganggu generalisasi hasil penelitian (Setyosari, 2013). Validitas eksternal dikontrol dengan cara memastikan faktorfaktor di atas dapat dihindari melalui komitmen yang ditanda tangani oleh subjek penelitian sebelum pretes.

Pengolahan dan analisis data menggunakan rumus rata-rata, Chi-kudrat, dan $\mathrm{t}$ test (Sugiyono, 2011). 


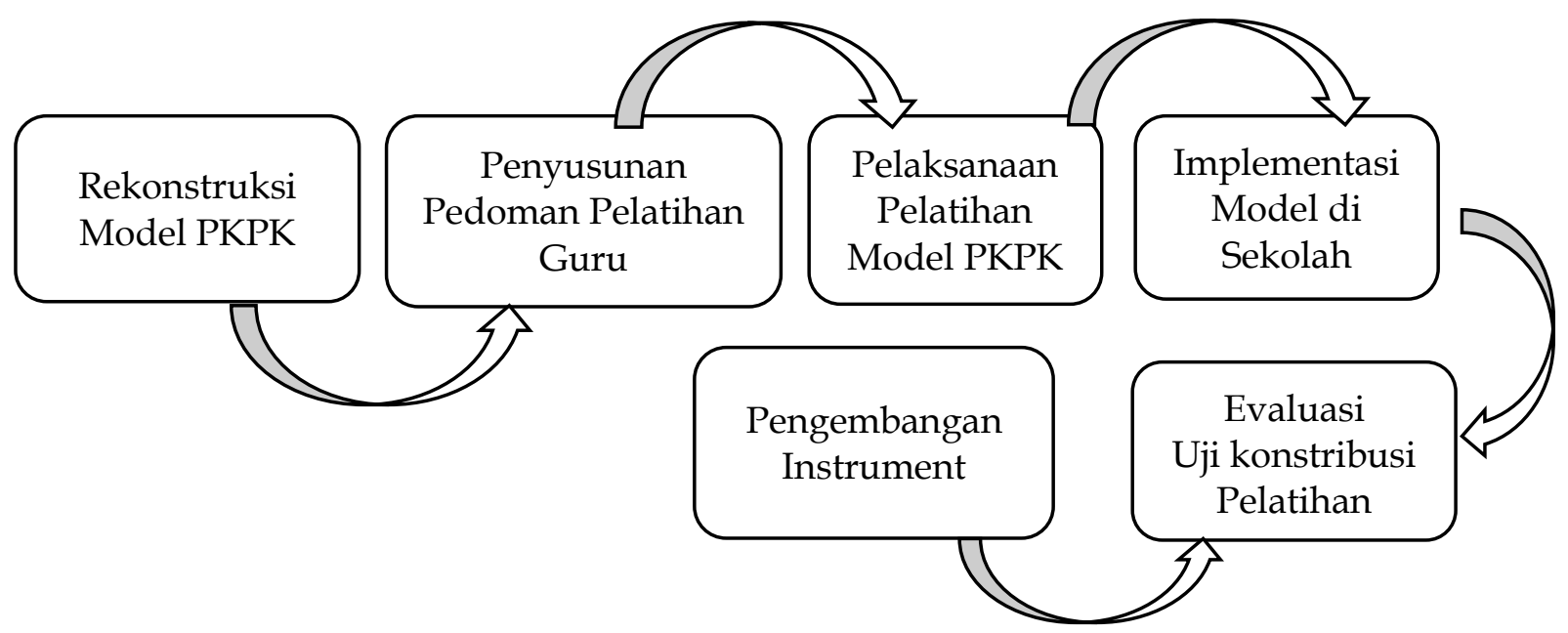

Gambar 3: Desain Penelitian

Gambar 3 menunjukkan desain penelitian mulai dari model PKPK rekonstruksi melalui penelitian; penyusunan panduan penggunaan oleh guru; penyusunan pedoman pelatihan (persiapan, praktik/pelaksanaan, danpenilaian); pelaksanan pelatihan model; penerapan model PKPK di lembaga PAUD oleh guru; penyusunan instrument penelitian; dan evaluasi melalui postes.

\section{HASIL DAN PEMBAHASAN}

Penelitian ini menguji hipotesis:

Ho: Tidak terdapat kontribusi kontribusi pelatihan dalam meningkatkan keterampilan membimbing siswa bermain balok.

Ha: Terdapat kontribusi pelatihan dalam meningkatkan keterampilan membimbing siswa bermain balok.

Hasil penelitian menyajikan data tentang mean, uji normalitas, dan uji hipotesis. Subjek penelitian yang dianalisis data postes sebanyak 68 orang $(N=68)$. Berikut disajikan rekapitulasi deskripsi data nilai akhir untuk kemampuan membimbing guru bermain balok adalah rata-rata (mean), gain score dan uji normalitas sebaran data (Chi-kuadrat), tabel 3.

Tabel 3. Hasil Analisis Pretes dan Posttest

\begin{tabular}{ccc}
\hline Hasil Analisis & Pre-test & Post-test \\
\hline Mean & 59,16 & 77,10 \\
Minimum & 50 & 67 \\
Maksimum & 68 & 85 \\
Panjang kelas & 18 & 18 \\
Jumlah kelas Interval & 5 & 5 \\
\hline
\end{tabular}

Berdasarkan hasil pretes diperoleh nilai rata-rata 59,16 dan hasil postes 77,10. Data tersebut menunjukkan adanya peningkatan keterampilan guru membimbing siswa bermain balok dari sebelum dan sesudah perlakuan atau pelatihan.

Hasil uji normalitas menggunakan rumus Chi-kuadrat pada pemberian post-test pada taraf signifikansi adalah $5 \%$ dan derajat kebebasan $=5$, diperoleh $\mathrm{X} 2$ hitung $=2,71$ dan $\mathrm{X} 2$ tabel $=11,07$, maka nilai X2 hitung $<$ X2 tabel, maka distribusi data nilai statistik 68 guru berdistribusi normal. Berdasarkan hal itu maka uji statistik yang digunakan dalam penelitian ini adalah uji-t dengan menggunakan rumus uji varians. Dari analisis uji hipotesis diperoleh hasil rekapitulasi analisis Uji t. 
Rekapitulasi Analisis Uji-t

\begin{tabular}{llllll}
\hline No & Populasi & N & t hitung & t tabel & Status \\
\hline $\mathbf{1}$ & Guru & 68 & 5,063 & 1,960 & Ha diterima \\
\hline
\end{tabular}

Dari hasil analisis diperoleh $\mathrm{t}$ hitung $=5,063>\mathrm{t}$ tabel $=1,960$ pada taraf signifikansi $5 \%(\mathrm{a}=$ $0,05)$, maka dengan demikian Ha diterima. Hal ini berarti bahwa terdapat kontribusi pelatihan dalam meningkatkan keterampilan guru dalam membimbing siswa bermain balok. Besaran perbedaan hasil pretes dan postes peningkatan dari setiap aspek, gambar 3.

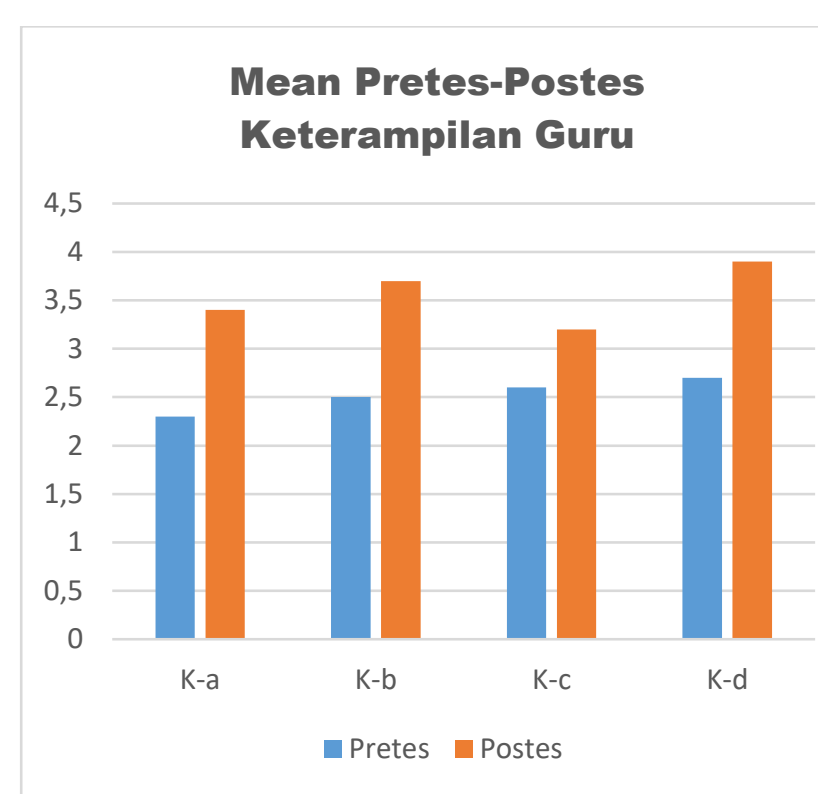
Gambar 3: Rata-rata Nilai Prestes dan Postes pada Kontribusi Pelatihan Terhadap keterampilan Guru

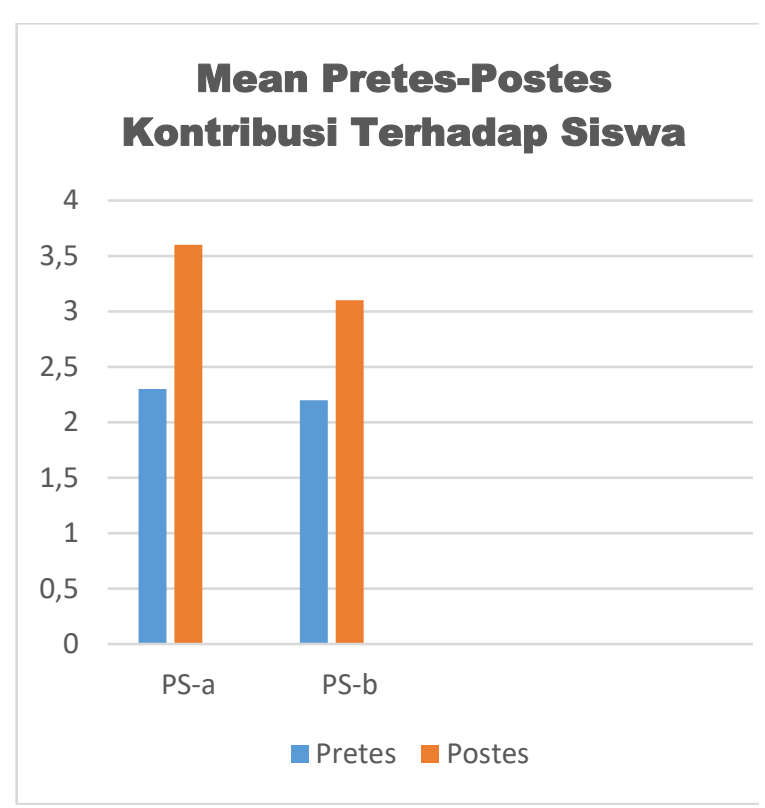

Gambar 4: Rata-rata Nilai Prestes dan Postes pada Kontribusi Peningkatan keterampilan Guru Terhadap Siswa

\section{Keterangan gambar 3:}

K-a adalah kontribusi terhadap keterampilan menguasai prosedur, skenario, tahapan, permainan balok; K-b adalah konstribusi terhadap keterampilan dalam melaksanakan proses bimbingan bermain kepada siswa secara menarik dan menyenangkan; K-c adalah konstribusi terhadap kemudahan penggunaan alat permainan dan pengaturan waktu bermain; dan K-d adalah kontribusi terhadap keterampilan menilai.

\section{Keterangan gambar 4:}

PS-a adalah partisipasi dan ketertarikan siswa bermain; PS-b adalah efektivitas proses bermain siswa.

Penelitian ini berupaya mengungkap apakah pelatihan tentang teknik permainan balok model PKPK berkontribusi dalam meningkatkan keterampilan guru dalam membimbing siswa bermain balok. Temuan penelitian menunjukkan bahwa pelatihan yang diberikan kepada guru sebelum kegiatan pembimbingan kepada siswa berkontribusi dalam meningkatkan keterampilan guru: (a) menguasai prosedur, skenario, tahapan, permainan balok: (b) melaksanakan proses kegiatan bimbingan bermain kepada siswa secara menarik dan menyenangkan; (c) kemudahan dalam penggunaan alat permainan dan pengaturan waktu bermain, (d) kemampuan dalam menilai kemampuan siswa. Peningkatan keterampilan membimbing guru tersebut diikuti peningkatan (i) partisipasi dan ketertarikan 
siswa dalam mengikuti permainan, dan (ii) efektivitas proses permainan siswa dalam mencapai tujuan permainan

Permainan balok merupakan salah sarana dalam mengembangkan tugas-tugas perkembangan anak usia dini. Permainan balok selain banyak digemari anak juga memberi manfaat luas terhadap perkembangan seperti pengalaman kreatif, imajinasi, dramatik, numerikal, berhitung, membaca, kemampuan bereksperimen, keterampilan tentang teknik (Bojorque. G. et al, 2018; Cohen \& Emmons, 2017; Hanline et al., 2010; Pankratz, 2015; Schmitt. S. A. et al, 2018; Simoncini et al., 2020). Menurut Piaget, dalam (Morrison G. S, 2012), kemampuan berpikir anak usia dini berada dalam tahap berpikir pra-operasional, sehingga untuk kegiatan-kegiatan yang berkaitan dengan berpikir abstrak membutuhkan bimbingan orang dewasa. Permainan balok membangun termasuk salah satu kegiatan bermain yang memacu imajinasi dan pengalaman berpikir kreatif (Borriello \& Liben, 2018; Pankratz, 2015) sehingga membutuhkan bantuan guru. Hal ini sejalan dengan pandangan Vygotsky bahwa bantuan orang dewasa dapat meningkatkan zone of proximal development (ZPD) dari kemampuan aktual (actual ability) atas usaha mandiri kepada kemampuan potensial (potential ability) lebih tinggi. Senada dengan itu, Rogoff, (1995); Wertsch, (1998) beranggapan bahwa secara prinsip teori Vygotsky dapat diaplikasikan pada permainan balok (Cohen \& Emmons, 2017).

Keterampilan guru dalam membimbing (guiding) dan mengamati (observing) permainan balok sangat dibutuhkan siswa terutama pada awal bermain. Data observasi lapangan dalam studi pendahuluan tentang hampir seluruh siswa taman kanak-kanak tidak bisa bermain balok secara efektif untuk tujuan meningkatkan kreativitas membuktikan bahwa mereka membutuhkan bimbingan guru (Mansipal, 2008). Sebelum dilepas bermain sendiri, siswa perlu dikenalkan jenis dan fungsi potongan balok, cara menghubungkan, membangun struktur, melengkapi dengan asesoris, dan menginterpretasikan bangunan struktur yang dibuat. Berdasarkan skenario permainan dalam model PKPK, bimbingan guru dilakukan pada awal bermain dan setelah itu siswa diberikan kesempatan mengembangkan imajinasi dan pengalaman kreatifnya melalui bermain sendiri atau berkelompok. Oleh karena itu, untuk meningkatkan keterampilan guru dalam menjalankan perannya sebagai pembimbing, pengamat, dan penilai dalam permainan konstruktif diperlukan pelatihan-pelatihan (Bailey \& Van Harken, 2014).

Pelatihan berkontribusi dalam meningkatkan keterampilan guru dalam menguasai prosedur, skenario, dan tahapan permainan. Guru yang telah dilatih ternyata lebih mampu dalam melaksanakan kegiatan bimbingan bermain dengan siswa berdasarkan prosedur, skenario dan tahapan permainan yang telah ditentukan. Hasil penelitian ini mendukung hasil penelitian terdahulu mengenai peranan pelatihan sebagai sarana efektif dalam meningkatkan kompetensi guru. Pelatihan, penataran, bengkel kerja (workshop), bimbingan teknis, penyegaran, in service training atau kegiatan sejenis sudah sejak lama digunakan sebagai sarana dalam meningkatkan kompetensi guru (Gliessman \& Pugh, 1994; Hyatt \& Filler, 2007; Nagovitsyn et al., 2016; Vodyasova, L. P., \& Morozova, n.d.). Pelatihan guru juga telah terbukti memberi konstribusi terhadap upaya mengembangkan kemampuan dan keterampilan dasar guru anak usia dini (Elprida et al., 2018; Loizou, 2009; Pereira, 2009).

Keterampilan dalam melaksanakan proses kegiatan bimbingan kepada siswa adalah sejauhmana guru mampu mengaplikasikan model tersebut dalam kegiatan bermain bersama siswa, mulai persiapan tempat, pengadaan alat main balok, penjelasan skenario, dan tahapan main, bimbingan bermain, berjalannya proses kreatif sampai penggunaan alat evaluasi. Temuan (Dobrescu \& Grosu, 2014; Rohmawati, 2015) pembelajaran efektif paling tidak didasarkan dua faktor, yaitu bagaimana membuat siswa mudah dan senang belajar, dan keberadaan guru kompeten. Kedua faktor ini juga menjadi prinsip bimbingan bermain balok model PKPK. Keterampilan dalam menciptakan kegiatan bermain yang menarik dan menyenangkan sangat penting dilakukan guru untuk merangsang minat dan ketertarikan siswa bermain sehingga dapat memacu kemampuan berpikir kreatif dan imajinasi anak. 
Belajar atau bermain hendaknya mengundang rasa antusiasme, inisiatif dan rasa suka siswa; terjadi komunikasi aktif antara guru-siswa, siswa dengan siswa; dan keterlibatan dan partisipasi siswa. Temuan (Agustin et al., 2021; Özdoğan, 2011) bahwa minat, ketertarikan, motivasi, dan kebermaknaan bagi siswa menjadi bagian penting dalam bermain. Sejalan dengan temuan tersebut, (Prameswari, S. J., \& Budiyanto, 2017) menyatakan bahwa guru dibutuhkan untuk mengkreasikan cara belajar efektif, dibantu oleh siswa dalam memahami perkembangan anak.

Peningkatan keterampilan guru dalam menguasai prosedur, skenario, tahapan, permainan balok, melaksanakan proses kegiatan bimbingan bermain kepada siswa secara menarik dan menyenangkan, kemudahan dalam penggunaan alat permainan dan pengaturan waktu bermain, dan kemampuan dalam menilai kemampuan siswa ternyata juga memberi dampak positif terhadap partisipasi dan ketertarikan siswa dalam bermain. Hal ini sejalan dengan pendapat bahwa kegiatan bimbingan bermain balok berdampak positif terhadap partisipasi siswa (Trawick-Smith et al., 2017).

\section{SIMPULAN}

Pelatihan teknik permainan balok model PKPK yang diikuti guru Raudhatul Athfal di Kecamatan Nagrek, Cicalengka, dan Cikancung, Kabupaten Bandung berkontribusi meningkatkan keterampilan guru dalam menguasai prosedur, skenario, tahapan permainan; melaksanakan proses kegiatan bimbingan bermain kepada siswa secara menarik dan menyenangkan; kemudahan dalam penggunaan alat permainan dan pengaturan waktu; kemampuan menilai siswa. Hasil penelitian ini berimplikasi bahwa pelatihan sebelum melaksanakan kegiatan bermain balok dengan siswa dapat meningkatkan keterampilan dalam mengaplikasikan model PKPK, oleh karena itu layak diikuti guru taman kanakkanak/raudhatul athfal.

\section{UCAPAN TERIMA KASIH}

Peneliti sekaligus pengembang teknik permainan balok model PKPK mengucapkan terima kasih dan apresiasi atas dorongan, kerja sama dan bantuan dari pihak yayasan, kepala sekolah, guru-guru seluruh Raudhatul Athfal (RA) di Kabupaten Bandung, Jawa Barat, khususnya kecamatan Nagrek, Cicalengka, dan Cikancung. Penghargaan yang tinggi peneliti sampaikan kepada yayasan dan kepala sekolah Yayasan Al Farouk, Cicalengka yang menjadi inspirator, motivator, sekaligus koordinator pelatihan bagi guru-guru di wilayah tersebut. Terima kasih kepada tim instruktur pelatihan yang bekerja keras dalam membimbing guruguru sehingga membawa manfaat bagi sekolah mereka terutama siswa. Semoga hasil penelitian ini menambah khasanah ilmu pengetahuan dan memberi manfaat kepada masyarakat.

\section{DAFTAR PUSTAKA}

Agustin, M., Inten, D. N., Permatasari, A. N., \& Mulyani, D. (2021). Strategi Guru PAUD dalam Mengembangkan Kecerdasan Interpersonal Anak Usia Dini di Saat Belajar dari Rumah. Jurnal Obsesi: Jurnal Pendidikan Anak Usia Dini, 5(2), 1997-2007. https://doi.org/10.31004/obsesi.v5i2.1055

Bailey, N. M., \& Van Harken, E. M. (2014). Visual Images as Tools of Teacher Inquiry. Journal of Teacher Education, 65(3), 241-260. https:// doi.org/10.1177/0022487113519130

Bairaktarova, D., Evangelou, D., \& Brophy, S. (2011). Early engineering in young children' s exploratory play with tangible materials. Children, Youth and Environments, 21(2), 212-235.

Bergen. D. (2002). The role of pretend play in children's cognitive development. Early childhood research and practive. http://ecrp.uiiuc.edu/v4n1/bergen.html

Bernard, H. R. (2013). Social Reseach Methode (Second). Sage Publication. 
Bojorque. G. et al. (2018). Effectiveness of Building Block Program for Enhancing Equadorian Kindergarten Numerical Competencies. Early Childhood Research Quarterly, 231-241. https:// doi.org/10.1016/j.ecresq.2017.12.009

Borriello, G. A., \& Liben, L. S. (2018). Encouraging Maternal Guidance of Preschoolers' Spatial Thinking During Block Play. Child Development, 89(4), 1209-1222. https:// doi.org/10.1111/cdev.12779

Brown. S. (2009). Play: How it shapes the brain, opens the imagination, and invigorates the soul. Penguin Group.

Bryman, A. (2016). Social Reseach Methode (Fifth). Oxford University Press. https://ktpu.kpi.ua/wp-content/uploads/2014/02/social-research-methods-alanbryman.pdf

Casey. B. M. et al. (2008). The Development of Spatial Skills Through Interventions Involving Block Building Activities. Cognition and Instruction Journal, 269-309. https:// doi.org/10.1080/07370000802177177

Cohen, L. E., \& Emmons, J. (2017). Block play: spatial language with preschool and schoolaged children. Early Child Development and Care, 187(5-6), 967-977. https:// doi.org/10.1080/03004430.2016.1223064

Creswell, J. . (n.d.). Educational Research: Planning, Conducting, and Evaluating Quantitative and Qualitative Research. : Prentice Hall.

Creswell, J. W. (2014). Qualitative, quantitative and mixed methods approaches. Sage.

Dobrescu, T., \& Grosu, E. F. (2014). Aspects Regarding Classroom Management and its Part in Making the Educational Process More Effective. Procedia - Social and Behavioral Sciences, 141, 465-469. https:// doi.org/10.1016/j.sbspro.2014.05.082

Dodge. D. T. et al. (2002). The Creative Curriculum for Preschool. Teaching Strategis Inc.

Elprida, S. K., ., Drs. I Wayan Sujana, S.Pd, M. P., \& ., Luh Ayu Tirtayani, S.Psi., M. P. (2018). Pengaruh Keterampilan Dasar Mengajar Guru Terhadap Perilaku Disiplin Pada Anak Usia Dini Kelompok B. Jurnal Pendidikan Anak Usia Dini Undiksha, 6(1), 11-20. https:// doi.org/10.23887/paud.v6i1.15047

Ferrara.K. et al. (2011). Block talk:Spatial language during block play. Mind, Brain, and Education. Journal Compilation International, Mind, Brain, Educational Society and Blackwell, 143-151. https:// doi.org/10.1111/j.1751-228X.2011.01122.x

Gliessman, D. H., \& Pugh, R. C. (1994). Concept and Skill Relationships in a Teacher Training Setting. Journal of Educational Research, 87(4), 211-218. https:// doi.org/10.1080/00220671.1994.9941245

Hanline, M. F., Milton, S., \& Phelps, P. C. (2010). The relationship between preschool block play and reading and maths abilities in early elementary school: A longitudinal study of children with and without disabilities. Early Child Development and Care, 180(8), 1005-1017. https:// doi.org/10.1080/03004430802671171

Hirsch. E. (1984). The Block Book. Revised ed. National Association for the Education of Young Children.

Hoorn. J. V. et al. (1993). Play at the Center of the Curriculum. Macmillan Publishing Company.

Hyatt, K. J., \& Filler, J. W. (2007). A comparison of the effects of two social skill training approaches on teacher and child behavior. Journal of Research in Childhood Education, 22(1), 85-96. https://doi.org/10.1080/02568540709594614

Hyson, M. (2004). (2004). The emotional development of young children. Teacher's College Press.

Kellar-Guenther, Y., Rosenberg, S. A., Block, S. R., \& Robinson, C. C. (2014). Parent involvement in early intervention: what role does setting play? Early Years, 34(1), 8193. https://doi.org/10.1080/09575146.2013.823382 
Loizou, E. (2009). In-service early childhood teachers reflect on their teacher training program: Reconceptualizing the case of Cyprus. Journal of Early Childhood Teacher Education, 30(3), 195-209. https:// doi.org/10.1080/10901020903084066

Mansipal, M. (2008). Model Pengembangan Kreativitas Melalui Permnainan Konstruktif Dalam Proses Pendidikan Anak Usia Dini (Studi terhadap Siswa Taman Kanak-Kanak di Bandung dan Cimahi. Unievrsitas Pendidikan Indonesia.

Masnipal, M. (2008). Model Pengembangan Kreativitas Melalui Permainan Konstruktif Dalam Proses Pendidikan Anak Usia Dini (Studi terhadap Siswa Taman Kanak-Kanak di Bandung dan Cimahi. Bandung). Universitas Pendidikan Indonesia.

Masnipal, M. (2016). Model Pengembangan Kreativitas Melalui Permainan Konstruktif dalam Meningkatkan Kemampuan Berpikir Kreatif Anak Usia Dini. Jurnal Pendidikan Islam Ta,Dib, 39-48. https:// doi.org/10.29313/tjpi.v5i1.2086

Masnipal, M. (2020). Building blocks play: Model reconstruction, teacher's guidance and early childhood creativity. Journal of Early Childhood Care and Education, 3(1), 14. https://doi.org/10.26555/jecce.v3i1.1763

Melhuish, E., Howard, S. J., Siraj, I., Neilsen-Hewett, C., Kingston, D., de Rosnay, M., Duursma, E., \& Luu, B. (2016). Fostering Effective Early Learning (FEEL) through a professional development programme for early childhood educators to improve professional practice and child outcomes in the year before formal schooling: Study protocol for a cluster randomised controlle. Trials, 17(1), 1-10. https:// doi.org/10.1186/s13063-016-1742-1

Morrison G. S. (2012). Fundamentals Of Early Childhood Education, 5 Th Edition. Pearson Education, Inc.

Nagovitsyn, N. K., Starygina, S. D., \& Gibadullina, E. A. (2016). Didactic engineering: Designing new generation learning systems. Integration of Education, 20(3), 393-406. https:// doi.org/10.15507/1991-9468.084.020.201603.393-406

Otsuka, K., \& Jay, T. (2017). Understanding and supporting block play: Video observation research on preschoolers' block play to identify features associated with the development of abstract thinking. Early Child Development and Care, 187(5-6), 9901003. https:// doi.org/10.1080/03004430.2016.1234466

Özdoğan, E. (2011). Play, mathematic and mathematical play in early childhood education. Procedia - Social and Behavioral Sciences, 15, 3118-3120. https://doi.org/10.1016/j.sbspro.2011.04.256

Palomino, M. del C. P. (2017). Teacher Training in the Use of ICT for Inclusion: Differences between Early Childhood and Primary Education. Procedia - Social and Behavioral Sciences, 237(June 2016), 144-149. https:// doi.org/10.1016/j.sbspro.2017.02.055

Pankratz, L. M. (2015). Building With Blocks: Incorporating Picture Books to Motivate and Guide Block Play in Kindergarten. Voices of Practitioners, 10(2), 64-79. http:/ / search.ebscohost.com/login.aspx?direct $=$ true\&db=ehh\&AN=35400750\&site=e host-live

Pereira, F. (2009). Conceptions and knowledge about childhood in initial teacher training: Changes in recent decades and their impact on teacher professionality, and on schooling in childhood. Teaching and Teacher Education, 25(8), 1009-1017. https://doi.org/10.1016/j.tate.2009.03.014

Pirrone, C., Tienken, C. H., Pagano, T., \& Di Nuovo, S. (2018). The Influence of Building Block Play on Mathematics Achievement and Logical and Divergent Thinking in Italian Primary School Mathematics Classes. Educational Forum, 82(1), 40-58. https://doi.org/10.1080/00131725.2018.1379581

Prameswari, S. J., \& Budiyanto, C. (2017). The development of the effective learning environment by creating an effective teaching in the classroom. Indonesian Journal of Informatics Education, 1(1), 79-86. https:// doi.org/10.20961/ijie.v1i1.11960 
Ramani, G., Zippert, E., Schweitzer, S., Hirsh-pasek, K., Hirsh-pasek, K., Fagan, T., Ramani, G. B., Zippert, E., Schweitzer, S., \& Pan, S. (n.d.). Preschool children ' s joint block building during a guided play activity Related papers.

Rohmawati, A. (2015). Efektivitas Pembelajaran. Jurnal Pendidikan Usia Dini, 9(1), 15-32.

Schmitt. S. A. et al. (2018). Using Block Play to Enhance Mathematics and executive Functioning: A Randomized Controlled Trial. Early Childhood Research, 181-191. https:// doi.org/10.1016/j.ecresq.2018.04.006

Setyosari, P. (2013). Metodologi Penelitian Pendidikan \& Pengembangan (Ke-5). Prenadamedia Group.

Simoncini, K., Forndran, A., Manson, E., Sawi, J., Philip, M., \& Kokinai, C. (2020). The Impact of Block Play on Children's Early Mathematics Skills in Rural Papua New Guinea. International Journal of Early Childhood, 52(1), 77-93. https:// doi.org/10.1007/s13158-020-00261-9

Sugiyono. (2011). Metode Penelitian Kuantitatif, Kualitatif dan R\&D. Alfabeta.

Trawick-Smith, J., Swaminathan, S., Baton, B., Danieluk, C., Marsh, S., \& Szarwacki, M. (2017). Block play and mathematics learning in preschool: The effects of building complexity, peer and teacher interactions in the block area, and replica play materials. Journal of Early Childhood Research, 15(4), 433-448. https:// doi.org/10.1177/1476718X16664557

Vodyasova, L. P., \& Morozova, E. N. 34-40. (n.d.). Intercultural competence as an indicator of professional maturity of a mobile teacher of the Russian language. Gumanitarnye Nauki i Obrazovaniye, 34-40. 